\title{
MODEL PENGAMBILAN KEPUTUSAN DENGAN TEKNIK METODE PROFILE MATCHING
}

\author{
Rianto Sitanggang ${ }^{1}$, Swono Sibagariang ${ }^{2}$ \\ ${ }^{1,2}$ Program Studi Sistem Informasi Universitas Sari Mutiara Indonesia \\ Jl. Kapten Muslim No. 79 Medan 20123 \\ ${ }^{1}$ rianto.sitanggang79@gmail.com, ${ }^{2}$ wnsibagariang@gmail.com
}

\begin{abstract}
Abstrak-Setiap bertambahnya kepentingan obyek yang menuntut dalam menentukan keputusan, maka akan semakin rumitlah realisasi pengambilan keputusan. Tetapi pengambil keputusan mesti membahas dan mencari keputusan yang paling utama dan tepat (the best). Ketika keputusan yang akan diambil sederhana seperti jam berapa harus bangun, jam berapa harus sarapan dan jam berapa harus kekantor atau jam berapa harus belajar maka biasanya seseorang dapat dengan mudah mengambil keputusan. Begitu juga dengan sebuah perusahaan ketika keputusan yang akan diambil bersifat kompleks dengan risiko yang besar seperti perumusan kebijakan, pengambil keputusan sering memerlukan alat bantu dalam bentuk analisis yang bersifat ilmiah, logis, dan terstruktur/konsisten. Salah satu alat analisis tersebut adalah berupa decision making model (model pembuatan keputusan) yang memungkinkan mereka untuk membuat keputusan untuk masalah yang bersifat kompleks. Aplikasi sistem pendukung keputusan yang dirancang dengan bahasa pemrograman PHP\&MySQL ini melakukan proses penilaian kinerja pegawai mulai dari penilaian kecerdasan, keahlian dan perilaku yang akan diputuskan dengan menggunakan metode Profile Matching dimana proses keputusan dengan penilaian berdasarkan bobot profil pada tiap-tiap pegawai.
\end{abstract}

Kata Kunci-Sistem Pendukung Keputusan, Profile Matching, Pegawai.

\section{PENDAhuluan}

Setiap bertambahnya kepentingan obyek yang menuntut anda untuk memilih keputusan, maka akan semakin rumitlah realisasi pengambilan keputusan. Siapapun pengambil keputusan, tidak akan mungkin menghindar dari pengambilan keputusan, baik itu untuk skala pribadi, keluarga, lingkungan, organisasi, maupun perusahaan. Karena keputusan selalu diperlukan untuk mengatasi masalah. Ketika keputusan yang akan diambil sederhana seperti jam berapa harus bangun, jam berapa harus sarapan dan jam berapa harus kekantor atau jam berapa harus belajar maka biasanya seseorang dapat dengan mudah mengambil keputusan.

Namun terkadang seringkali seseorang dihadapkan pada permasalahan yang perlu dipertimbangkan matang-matang sebelum mengambil keputusan seperti memilih pasangan hidup yang tepat, kapan saat yang tepat untuk menikah, kemanakah melanjutkan sekolah, atau jurusan apa yang paling tepat. Semua keputusan yang dibuat, tentunya didasari pada pertimbangan matang dari berbagai kemungkinan yang ada agar keputusan mendapat pilihan yang terbaik. Begitu juga dengan sebuah perusahaan ketika keputusan yang akan diambil bersifat kompleks dengan risiko yang besar seperti perumusan kebijakan, pengambil keputusan sering memerlukan alat bantu dalam bentuk analisis yang bersifat ilmiah, logis, dan terstruktur/konsisten. Salah satu alat analisis tersebut adalah berupa decision making model (model pembuatan keputusan) yang memungkinkan mereka untuk membuat keputusan untuk masalah yang bersifat kompleks. Lembaga penelitian seperti Badan Penelitian dan Pengembangan yang dikelola oleh pemerintah juga harus membuat berbagai keputusan.

Salah satu jenis keputusan yang paling sering dibuat adalah dalam menyusun prioritas (memilih) penelitian dari berbagai alternatif/pilihan topik/proposal penelitian. Setiap tahun lembaga penelitian dihadapkan pada ratusan proposal penelitian. Di sisi lain, sumberdaya, baik itu sumberdaya manusia, waktu, dan dana yang tersedia terbatas sehingga tidak memungkinkan untuk menjalankan semua penelitian tersebut.

Dalam hal ini, manajemen lembaga penelitian harus menyusun prioritas penelitian berdasarkan kriteria- kriteria yang telah disepakati untuk meyeleksi tenaga kerja.

Tenaga kerja (pegawai/karyawan) merupakan salah satu asset yang harus dimiliki oleh oraganisasi atau perusahaan. Tenaga kerja yang memiliki keahlian dan berdedikasi tinggi memudahkan perusahaan dalam mengelola aktivitasnya sehingga tujuan yang ditetapkan dapat tercapai. Untuk mendapatkan tenaga kerja (Sumber Daya Manusia /SDM) yang berkualitas bukanlah mudah. Salah satu cara yang digunakan untuk memperoleh tenaga kerja yang berkualitas adalah dengan melakukan pemilihan calon tenaga kerja. Pemilihan calon tenaga kerja ini merupakan tahapan untuk memutuskan apakah seorang pelamar dinyatakan diterima atau tidak. Keputusan yang akan diambil diharapkan dapat sesuai dengan harapan sehingga tidak ada pihak yang dirugikan. Berdasarkan latar belakang masalah, maka penulis 
mengangkat judul "Sistem Pengambilan Keputusan (SPK) Penilaian Pegawai ".

\section{TINJAUAN PUSTAKA}

Page | 45 Intelligence atau Intelegensia adalah seorang yang pandai melaksanakan pengetahuan yang dimilikinya. Dengan pengertian tersebut diatas maka dapat ditarik suatu kesimpulan bahwa walaupun seorang banyak memiliki pengetahuan, tetapi bila ia tidak bias melaksanakannya dalam praktek, maka ia tidak dapat di golongkan kedalam intelegensia. Dengan kata lain, intelegensia adalah kemampuan manusia untuk memperoleh pengetauan dan pandai melaksanakannya dalam praktek. Hal ini berarti kemampuan dalam berfikir dan menalar.

Bagian utama aplikasi Artifical Intelligence adalah pengetahuan (Knowledge), suatu pengertian tentang beberapa wilayah subjek yang diperoleh melalui pendidikan dan pengalaman.

\section{B. Ruang Lingkup Artificial Intelligence (IA)}

Hampir semua pangkalan pengetahuan (Knowledge base) sangat terbatas dalam arti terfokuskan kepada suatu masalah khusus. Pada saat pangkalan pengetahuan itu sudah terbentuk, maka teknik Artificial Intelligence bisa digunakan untuk memberi kemampuan baru kepada computer agar bisa berfikir, menalar, dan membuat inferensi (mengambil keputusan berdasarkan pengalaman) dan membuat pertimbangan-pertimbangan yang didasarkan oleh fakta-fakta atau aturan-aturan dan hubunganhubungannya yang terkandung dalam pangkalan pengetahuan tersebut.

Tujuan kedua Artificial Intelligence adalah untuk bisa memahami intelegensia manusia. Dengan menerapkan pola berfikir manusia pada komputer, maka pengguna dilatih untuk belajar bagaimana cara menyimpan pengetahuan dalam otak dan bagaimana cara menProfile Matching likasikannya.

\section{Sistem Pendukung Keputusan (Decision Support System)}

Sistem Pendukung Keputusan adalah suatu sistem yang ditujukan untuk mendukung manajemen pegambilan keputusan. Sistem berbasis model yang terdiri dari prosedur-prosedur dalam pemrosesan data dan pertimbangannya untuk membantu manajer dalam mengambil keputusan agar berhasil mencapai tujuannya[4]. Dengan berarti bahwa sistem ini harus berbasis komputer dan digunakan sebagai tambahan dari kemampuan penyeleksian masalah dari seseorang. Proses pengambilan keputusan terdiri dari 3 fase proses :

a. Intelligence : Pencarian kondisi-kondisi yang dapat menghasilkan keputusan

b. Design : Menemukan, mengembangkan, dan menganalisis materi- materi yang mungkin untuk dikerjakan c. Choice : Pemilihan dari materi - materi yang tersedia, mana yang akan dikejakan

Fase 1 sampai 3 merupakan dasar pengambilan keputusan, yang diakhiri dengan suatu rekomendasi. Sedangkan pemecahan masalah adalah serupa dengan pengambilan keputusan (fase 1 sampai 3) ditambah dengan implementasi dari rekomendasi (fase 4). Untuk pemecahan/penyelesaian masalah tak hanya mengacu kke solusi dari area masalah /kesulitan kesulitan tapi mencakup juga penyelidikan mengenai kesempatan-kesempatan yang ada.

\section{Profile Matching (GAP)}

Profile Matching yaitu ukuran kemampuan sebuah alat untuk dapat berkomunikasi dengan alat dari produsen lainnya[1]. Yang dimaksud dengan Profile Matching disini adalah beda antara profil penilaian kriteria dengan profil pegawai/karyawan. Proses perhitungan Profile Matching dilakukan untuk menentukan rekomendasi pegawai/karyawan dalam sistem penerimaan calon pegawai baru. Untuk pemetaan Profile Matching ini dilakukan dengan cara: menentukan ranking kandidat. Dalam penentuan peringkat (ranking) kandidat perlu dilakukan profile matching. Hasil akhir dari proses profile matching adalah ranking dari kandidat yang diajukan untuk mengisi lowongan kerja.

Pembobotan pada metode Profile Matching, merupakan nilai pasti yang tegas pada nilai tertentu karena nilai-nilai yang ada merupakan anggota himpunan tegas (crisp set)[5]. Di dalam himpunan tegas, keanggotaan suatu unsur di dalam himpunan dinyatakan secara tegas, apakah objek tersebut anggota himpunan atau bukan dengan menggunakan fungsi karakteristik.

Langkah-langkah metode profile matching adalah:

1. Menentukan variabel data-data yang dibutuhkan.

2. Menentukan aspek-aspek yang digunakan untuk penilaian.

3. Pemetaan Gap profil. Gap = Profil Minimal - Profil data tes

4. Setelah diperoleh nilai Gap selanjutnya diberikan bobot untuk masing-masing nilai Gap.

5. Perhitungan dan pengelompokan Core Factor dan Secondary Factor. Setelah menentukan bobot nilai gap, kemudian dikelompokan menjadi 2 kelompok yaitu:

a. Core Factor (Faktor Utama), yaitu merupakan kriteria (kompetensi) yang paling penting atau menonjol atau paling dibutuhkan oleh suatu penilaian yang diharapkan dapat memperoleh hasil yang optimal.

\section{NFC $=$ ENC $/$ EIC}

Keterangan:

NFC : Nilai rata-rata core factor

$\mathrm{NC}$ : Jumlah total nilai core factor

IC : Jumlah item core factor 
b. Secondary Factor (faktor pendukung), yaitu merupakan item-item selain yang ada pada core factor.

Atau dengan kata lain merupakan faktor pendukung yang kurang dibutuhkan oleh suatu penilaian.

Page | 46

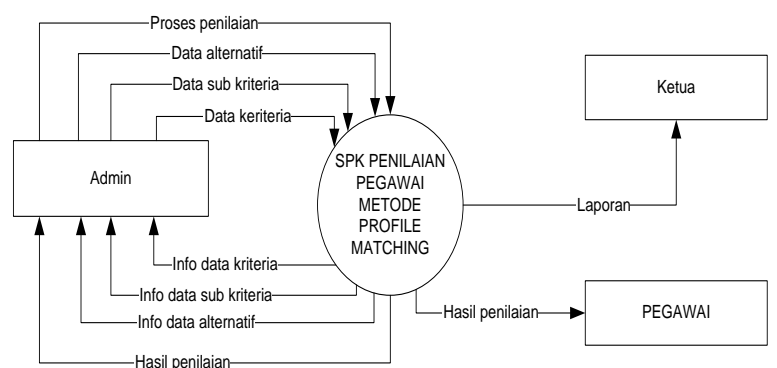

Gbr1. Konteks Diagram Sistem

Keterangan Event list :

1. Input Data Alternatif (Pegawai)

Admin menginputkan data pegawai yang akan dilakukan proses pemilihan perangkingan pegawai berprestasi maka sistem akan memberikan informasi kembali mengenai informasi pegawai.

2. Input Kriteria Penilaian

Kriteria penilaian merupakan jenis-jenis kriteria apa saja yang akan dinilai dalam sistem pendukung keputusan yang diinputkan oleh admin.

3. Input Kriteria Penilaian Pegawai

Kriteria penilaian pegawai yang inputkan oleh admin merupakan pengesetan kriteria apa saja yang dimiliki oleh pegawai.

4. Hasil Penilaian

Hasil penilaian akan diperoleh oleh admin atau bagian akademik seteleh proses dari sistem pendukung keputusan dilakukan. Hasil berupa perangkingan prestasi. Hasil penilaian juga akan diinformasikan kepada pegawai melalui pengumuman hasil proses seleksi.

5. Laporan

Semua kegiatan dan informasi yang tersimpan didalam sistem dapat diinformasikan kepada ketua berupa laporan.

\section{PEMBAHASAN}

Perancangan proses menggambarkan alur proses dari sistem yang akan dirancang mulai dari bagian inputan data, pengeditanm data, tampil data serta penghapusan data. Rancangan proses juga menggambarkan input dan output dari sistem yang akan dihasilkan.

\section{Konteks Diagram (Diagram Context)}

Konteks diagram untuk menggambarkan keseluruhan dari sistem yang dirancang. Adapun perancangannya dapat dilihat pada gambar 1 berikut :

\section{A. Analisa Sistem}

Sistem Pengambilan Keputusan (SPK) penilaian kinerja pegawai ini digunakan untuk mengelola datadata yang berhubungan dengan seleksi kelayakan seseorang pegawai.

Sistem ini memiliki fungsi antara lain :

a. Menampung data-data yang berhubungan dengan seleksi calon pegawai.

b. Menghasilkan informasi yang cepat dan akurat bagi pengambilan keputusan kinerja karyawan.

c. Memudahkan dalam pengambil keputusan karena sistem ini digunakan sebagai alat bantu pengambilan keputusan. 
d. Melakukan pengelolaan data kriteria calon pegawai yang baik.

\section{B. Perhitungan Profile Matching}

Perhitungan pemetaan gap meliputi tiga aspek yaitu, kecerdasan, keahlian dan perilaku.

Page | 47 Pengumpulan gap yang terjadi pada setiap penilaian memiliki perhitungan yang berbeda[6].

Untuk lebih jelasnya akan dipaparkan untuk tiap penilaiannya, dimana meliputi:

a. Kecerdasan

Pada penilaian ini, dilakukan proses perhitungan gap antara kriteria calon pegawai dan penilaian. Untuk penilaian kecerdasan psikologi berjumlah 10 sub penilaian, kemudian gap tersebut dikumpulkan menjadi 2 tabel yang terdiri dari : field '(-)', untuk menempatkan jumlah dari nilai gap yang bernilai negatif, sedangkan field ' $(+)$ ', untuk jumlah dari nilai gap yang bernilai positif. Sebagai contoh, dapat dilihat pada tabel 1 :

TABEL I

PENILAIAN KECERDASAN UNTUK PENGELOMPOKAN

\begin{tabular}{|c|c|c|c|c|c|c|c|c|c|c|c|c|}
\hline $\begin{array}{l}\mathbf{N} \\
\mathbf{0}\end{array}$ & $\begin{array}{l}\text { ID_P } \\
\text { eng }\end{array}$ & 1 & 2 & 3 & 4 & 5 & 6 & 7 & 8 & 9 & $\begin{array}{l}\mathbf{I} \\
\mathbf{Q}\end{array}$ & \\
\hline 1 & $\begin{array}{l}\text { P000 } \\
1 \\
\end{array}$ & 2 & 4 & 3 & 3 & 2 & 2 & 4 & 3 & 2 & 3 & \\
\hline 2 & $\begin{array}{l}\text { P000 } \\
2\end{array}$ & 3 & 4 & 3 & 3 & 2 & 3 & 4 & 2 & 4 & 4 & \\
\hline 3 & $\begin{array}{l}\text { P000 } \\
3 \\
\end{array}$ & 4 & 4 & 3 & 3 & 4 & 3 & 2 & 3 & 3 & 2 & \\
\hline 4 & $\begin{array}{l}\text { P000 } \\
4\end{array}$ & 3 & 5 & 4 & 3 & 4 & 4 & 4 & 5 & 4 & 3 & \\
\hline 5 & $\begin{array}{l}\text { P000 } \\
5\end{array}$ & 3 & 3 & 3 & 1 & 2 & 5 & 5 & 2 & 5 & 4 & \\
\hline \multicolumn{2}{|c|}{ Profile } & 3 & 3 & 4 & 3 & 4 & 4 & 5 & 3 & 3 & 4 & \\
\hline 1 & $\begin{array}{l}\text { P000 } \\
1\end{array}$ & $\begin{array}{l}- \\
1\end{array}$ & 1 & $\begin{array}{l}- \\
1\end{array}$ & 0 & - & $\begin{array}{l}- \\
2\end{array}$ & $\begin{array}{l}- \\
1\end{array}$ & 0 & $\begin{array}{l}- \\
1\end{array}$ & $\begin{array}{l}- \\
1\end{array}$ & \multirow{5}{*}{$\begin{array}{l}\text { G } \\
\text { ap }\end{array}$} \\
\hline 2 & $\begin{array}{l}\text { P000 } \\
2 \\
\end{array}$ & 0 & 1 & $\begin{array}{l}- \\
1 \\
\end{array}$ & 0 & - & $\begin{array}{l}- \\
1 \\
\end{array}$ & $\begin{array}{l}- \\
1 \\
\end{array}$ & \begin{tabular}{l|}
- \\
1 \\
\end{tabular} & 0 & 0 & \\
\hline 3 & $\begin{array}{l}\text { P000 } \\
3\end{array}$ & 1 & 1 & $\begin{array}{l}- \\
1\end{array}$ & 0 & 0 & $\begin{array}{l}- \\
1\end{array}$ & $\begin{array}{l}- \\
3\end{array}$ & 0 & $\begin{array}{l}- \\
1\end{array}$ & $\begin{array}{l}- \\
2\end{array}$ & \\
\hline 4 & $\begin{array}{l}\text { P000 } \\
4\end{array}$ & 0 & 2 & 0 & 0 & 0 & 0 & $\begin{array}{l}- \\
1 \\
\end{array}$ & 2 & 0 & $\begin{array}{l}- \\
1\end{array}$ & \\
\hline & $\begin{array}{l}\text { P000 } \\
5 \\
\end{array}$ & 0 & 0 & \begin{tabular}{l|}
- \\
1 \\
\end{tabular} & $\begin{array}{l}- \\
2 \\
\end{array}$ & $\begin{array}{l}- \\
2 \\
\end{array}$ & 1 & 0 & \begin{tabular}{l|}
- \\
1 \\
\end{tabular} & 1 & 0 & \\
\hline
\end{tabular}

Keterangan :
1 : Common Sense
2 : Verbalisasi Ide
3 : Sistematika Berpikir
4 : Penalaran dan Solusi Real
5 : Konsentrasi
6 : Logika Praktis.
7 : Fleksibilitas Berpikir
8 : Imajinasi Kreatif
9: Antisipasi
IQ : Potensi Kecerdasan

Dapat dilihat pada Tabel 1 bahwa profile untuk tiap sub-aspek yang tertera dalam tabel tersebut adalah sebagai berikut: $(1)=3,(2)=3,(3)=4,(4)=$ $4,(5)=3,(6)=4,(7)=4,(8)=5,(9)=3$, dan (IQ) $=$ 4.

Kemudian sebagai contoh, diambil calon pegawai dengan Id_Peng K001 dimana profilnya adalah: $(1)=$ $2,(2)=4,(3)=3,(4)=3,(5)=2,(6)=2,(7)=4,(8)$ $=3,(9)=2$, dan $(\mathrm{IQ})=3$.

Sehingga hasil gap yang terjadi untuk tiap sub penilainnya adalah: $(1)=-1,(2)=1,(3)=-1,(4)=-1$, $(5)=-1,(6)=-2,(7)=0,(8)=-2,(9)=-1$, dan $(I Q)=$ -1 .

\section{b. Keahlian}

Cara perhitungan untuk field gap kenilaian keahlian sama dengan perhitungan dengan penilaian kecerdasan. Contoh perhitungan dapat dilihat pada tabel 2 :

TABEL II

PENILAIAN KEAHLIAN UNTUK PENGELOMPOKAN GAP

\begin{tabular}{|c|c|c|c|c|c|}
\hline No & ID_Peng & BDB & MPM & MBI & \\
\hline 1 & P0001 & 2 & 4 & 2 & \\
\hline 2 & P0002 & 4 & 4 & 2 & \\
\hline 3 & $\mathrm{P} 0003$ & 4 & 4 & 3 & \\
\hline 4 & P0004 & 3 & 5 & 4 & \\
\hline 5 & P0005 & 3 & 3 & 3 & \\
\hline \multicolumn{2}{|c|}{ Profile } & 4 & 5 & 4 & \\
\hline & P0001 & -2 & -1 & -2 & \multirow{5}{*}{ Gap } \\
\hline 2 & P0002 & 0 & -1 & -2 & \\
\hline 3 & P0003 & 0 & -1 & -1 & \\
\hline 4 & P0004 & -1 & 0 & 0 & \\
\hline 5 & P0005 & -1 & -2 & -1 & \\
\hline
\end{tabular}

Keterangan :

BDM : Berkomunikasi Dengan Baik

MPM : Menguasai Pengoperasi Microsoft Office

MBI : Mampu Berbasaha Inggris

Dapat dilihat pada Tabel 2 bahwa bobot dari profile meliputi: $(\mathrm{BDM})=4,(\mathrm{MPM})=5,(\mathrm{MBI})=4$. Kemudian diambil contoh untuk profile dari calon pegawai dengan Id_Peng K001 dengan penilaian sebagai berikut: $(\mathrm{BDM})=2,(\mathrm{MPM})=4,(\mathrm{MBI})=2$.

Sehingga hasil gap yang terjadi untuk tiap penilaiannya adalah $:(\mathrm{BDM})=-2,(\mathrm{MPM})=-1$, $(\mathrm{MBI})=-2$.

\section{c. Perilaku}

Cara perhitungan untuk field gap-nya pun sama dengan perhitungan pada aspek keahlian. Contoh perhitungan dapat dilihat pada Tabel 3 :

TABEL 3

PENILAIAN PERILAKU UNTUK PENGELOMPOKAN GAP

\begin{tabular}{|l|l|l|l|l|l|l|}
\hline No & ID_Peng & DO & IN & ST & CO & \\
\hline 1 & P0001 & 4 & 4 & 4 & 4 & \\
\hline 2 & P0002 & 4 & 3 & 4 & 4 & \\
\hline 3 & P0003 & 4 & 5 & 5 & 2 & \\
\hline
\end{tabular}




\begin{tabular}{|l|l|l|l|l|l|l|}
4 & $\mathrm{P} 0004$ & 3 & 3 & 4 & 5 & \\
\hline 5 & $\mathrm{P} 0005$ & 4 & 3 & 3 & 5 & \\
\hline \multicolumn{2}{|l|l|l|l|l|l}{} & 3 & 3 & 4 & 5 & \\
\hline 1 & $\mathrm{P} 0001$ & 1 & 1 & 0 & -1 & Gap \\
\hline 2 & $\mathrm{P} 0002$ & 1 & 0 & 0 & -1 & \\
\hline 3 & $\mathrm{P} 0003$ & 1 & 2 & 1 & -3 & \\
\hline 4 & $\mathrm{P} 0004$ & 0 & 0 & 0 & 0 & \\
\hline 5 & $\mathrm{P} 0005$ & 1 & 0 & -1 & 0 & \\
\hline
\end{tabular}

Keterangan :
DO : Dominance (Kekuasaan)
IN : Influences (Pengaruh)
ST : Steadiness (Keteguhan Hati)
$\mathrm{CO} \quad$ : Compliance (Pemenuhan)

Dapat dilihat pada Tabel 3 bahwa bobot dari profile pada aspek Perilaku ini antara lain: $(\mathrm{DO})=3$, $(\mathrm{IN})=3,\left(\mathrm{~S} \_3\right)=4$, dan $(\mathrm{CO})=5$.

Seperti contohnya calon pegawai dengan Id_Peng P0001 dengan kriteria: $(\mathrm{DO})=4,(\mathrm{IN})=4,(\mathrm{ST})=4$ dan $(\mathrm{CO})=4$. Sehingga dengan nilai yang sudah ada maka dapat dilihat bahwa hasil perhitungan gap yang terjadi dari calon pegawai yang bersangkutan adalah : $(\mathrm{DO})=1,(\mathrm{IN})=1,(\mathrm{ST})=0$ dan $(\mathrm{CO})=-1$.

Setelah didapatkan tiap gap masing-masing calon pegawai maka tiap profil calon pegawai diberi bobot nilai dengan patokan tabel bobot nilai gap. Seperti yang dapat dilihat pada Tabel 4 di bawah ini :

TABEL 4

TABEL BOBOT NILAI GAP

\begin{tabular}{|l|l|l|l|}
\hline No & Selisih & $\begin{array}{l}\text { Bobot } \\
\text { Nilai }\end{array}$ & Keterangan \\
\hline 1 & 0 & 5 & $\begin{array}{l}\text { Tidak ada selisih } \\
\text { (Kompetensi sesuai } \\
\text { dengan yang dibutuhkan }\end{array}$ \\
\hline 2 & 1 & 4,5 & $\begin{array}{l}\text { Kompetensi individu } \\
\text { kelebihan 1 tingkat / level }\end{array}$ \\
\hline 3 & -1 & 4 & $\begin{array}{l}\text { Kompetensi individu } \\
\text { kekurangan 1 tingkat / } \\
\text { level }\end{array}$ \\
\hline 4 & 2 & 3,5 & $\begin{array}{l}\text { Kompetensi individu } \\
\text { kelebihan 2 tingkat / level }\end{array}$ \\
\hline 5 & -2 & 3 & $\begin{array}{l}\text { Kompetensi individu } \\
\text { kekurangan 2 tingkat / } \\
\text { level }\end{array}$ \\
\hline 6 & 3 & 2 & $\begin{array}{l}\text { Kompetensi individu } \\
\text { kelebihan 3 tingkat / level }\end{array}$ \\
\hline 7 & -3 & 2,5 & $\begin{array}{l}\text { Kompetensi individu } \\
\text { kekurangan 3 tingkat / } \\
\text { level }\end{array}$ \\
\hline 9 & 4 & 1,5 & $\begin{array}{l}\text { Kompetensi individu } \\
\text { kelebihan 4 tingkat / level }\end{array}$ \\
\hline
\end{tabular}

Sehingga tiap calon pegawai akan memiliki tabel bobot seperti contoh-contoh tabel yang ada di bawah ini.

Contoh hasil pemetaan gap Kompetensi Kecerdasan :

TABEL 5

TABEL KAPASITAS KECERDASAN HASIL PEMETAAN GAP

\begin{tabular}{|l|l|l|l|l|l|l|l|l|l|l|l|}
\hline $\begin{array}{l}\text { N } \\
\text { o }\end{array}$ & $\begin{array}{l}\text { ID_Pe } \\
\text { ng }\end{array}$ & $\mathbf{1}$ & $\mathbf{2}$ & $\mathbf{3}$ & $\mathbf{4}$ & $\mathbf{5}$ & $\mathbf{6}$ & $\mathbf{7}$ & $\mathbf{8}$ & $\mathbf{9}$ & $\begin{array}{l}\text { I } \\
\mathbf{Q}\end{array}$ \\
\hline 1 & P0001 & - & & - & & - & - & - & & - & \\
& 1 & 1 & 1 & 0 & 2 & 2 & 1 & 0 & 1 & -1 \\
\hline
\end{tabular}

Dengan profil calon pegawai seperti terlihat pada tabel di atas dan dengan acuan pada tabel bobot nilai gap seperti ditunjukkan pada Tabel 5, maka calon pegawai dengan Id_Peng P0001 akan memiliki nilai bobot tiap sub-aspeknya seperti terlihat pada Tabel 6 di bawah ini:

TABEL 6

TABEL KAPASITAS KECERDASAN HASIL BOBOT NILAI GAP

\begin{tabular}{|l|l|l|l|l|l|l|l|l|l|l|l|}
\hline $\begin{array}{l}\text { N } \\
\text { o }\end{array}$ & $\begin{array}{l}\text { ID_Pe } \\
\text { ng }\end{array}$ & $\mathbf{1}$ & $\mathbf{2}$ & $\mathbf{3}$ & $\mathbf{4}$ & $\mathbf{5}$ & $\mathbf{6}$ & $\mathbf{7}$ & $\mathbf{8}$ & $\mathbf{9}$ & $\begin{array}{l}\text { I } \\
\mathbf{Q}\end{array}$ \\
\hline 1 & P0001 & 4 & $\begin{array}{l}4 . \\
5\end{array}$ & 4 & 4 & 4 & 3 & 5 & 3 & 4 & 4 \\
\hline
\end{tabular}

Contoh hasil pemetaan gap kompetensi Keahlian :

TABEL 7

TABEL KEAHLIAN HASIL PEMETAAN GAP KOMPETENSI

\begin{tabular}{|l|l|l|l|l|}
\hline No & ID_Peng & BDB & MPM & MBI \\
\hline 1 & P0001 & 1 & 0 & -1 \\
\hline
\end{tabular}

Menjadi bobot nilai gap seperti pada Tabel 8 di bawah ini:

TABEL 8

TABEL KEAHLIAN HASIL BOBOT NILAI GAP

\begin{tabular}{|l|l|l|l|l|}
\hline No & ID_Peng & BDB & MPM & MBI \\
\hline 1 & P0001 & 4.5 & 5 & 4 \\
\hline
\end{tabular}

Demikian pula dengan hasil pemetaan gap kompetensi Perilaku :

TABEL 9

TABEL PERILAKU HASIL PEMETAAN GAP KOMPETENSI

\begin{tabular}{|l|l|l|l|l|l|}
\hline No & ID_Peng & DO & IN & ST & CO \\
\hline 1 & P0001 & 1 & 1 & 0 & -1 \\
\hline
\end{tabular}

Dengan bobot nilai gap seperti pada Tabel 10 di bawah ini:

TABEL 10

TABEL PERILAKU HASIL BOBOT NILAI GAP

\begin{tabular}{|l|l|l|l|l|l|}
\hline No & ID_Peng & DO & IN & ST & CO \\
\hline 1 & P0001 & 4.5 & 4.5 & 5 & 4 \\
\hline
\end{tabular}

C. Perhitungan dan Pengelompokan Core dan Secondary Factor 
Setelah menentukan bobot nilai gap untuk ketiga aspek yaitu aspek kecerdasan, keahlian dan perilaku dengan cara yang sama. Kemudian tiap aspek dikelompokkan menjadi 2 kelompok yaitu kelompok Core Factor dan Secondary Factor. Untuk perhitungan core factor dapat ditunjukkan pada rumus Page 149 di bawah ini

$$
N C F=\frac{\sum N C(k a, k e, p e)}{\sum I C}
$$

Keterangan:

$$
\begin{array}{ll}
\mathrm{NCF} & : \text { Nilai rata-rata core factor } \\
\mathrm{NC}(k a, k e, p e) & : \text { Jumlah total nilai core factor } \\
& (\text { Kecerdasan, Keahlian, } \\
& \text { Perilaku) } \\
& : \text { Jumlah item core factor }
\end{array}
$$

Sedangkan untuk perhitungan secondary factor dapat ditunjukkan pada rumus di bawah ini:

Keterangan:

$$
N S F=\frac{\sum N S(k a, k e, p e)}{\sum I S}
$$

$$
\begin{array}{ll}
\text { NSF } & : \begin{array}{l}
\text { Nilai rata-rata secondary } \\
\text { factor }
\end{array} \\
\mathrm{NS}(k a, k e, p e) & : \begin{array}{l}
\text { Jumlah total nilai secondary } \\
\text { factor } \quad \text { Kecerdasan, } \\
\end{array} \\
& \text { Keahlian, Perilaku) } \\
\mathrm{IS} & \text { Jumlah item secondary factor }
\end{array}
$$

Untuk lebih jelasnya pengelompokkan bobot nilai gap dapat dilihat pada contoh perhitungan aspek kapasitas kecerdasan, keahlian dan perilaku sebagai berikut:

a. Aspek Kapasitas Kecerdasan

Untuk penghitungan core factor dan secondary factor untuk aspek kapasitas kecerdasan, dengan terlebih dahulu menentukan sub-aspek mana yang menjadi core factor dari aspek kapasitas kecerdasan (misalnya sub-aspek 1, 2, 5, 8 dan 9) maka sub-aspek sisanya akan menjadi secondary factor. Kemudian nilai core factor dan secondary factor ini dijumlahkan sesuai rumus dan hasilnya dapat dilihat pada Tabel 11, berikut cara pengerjaannya:

$$
\begin{gathered}
N C F=\frac{4+4,5+4+3+4}{5}=\frac{19,5}{5}=3,9 \\
N C F=\frac{4+4+3+5+4}{5}=\frac{2}{5}=4
\end{gathered}
$$

TABEL 11

TABEL PENGELOMPOKKAN BOBOT NILAI GAP ASPEK

\begin{tabular}{|l|l|l|l|l|l|l|l|l|l|l|l|l|l|}
\hline $\begin{array}{l}\mathbf{N} \\
\mathbf{o}\end{array}$ & ID & $\mathbf{1}$ & $\mathbf{2}$ & $\mathbf{3}$ & $\mathbf{4}$ & $\mathbf{5}$ & $\mathbf{6}$ & $\mathbf{7}$ & $\mathbf{8}$ & $\mathbf{9}$ & $\mathbf{I}$ & $\mathbf{C}$ & $\mathbf{S}$ \\
\hline & $\mathrm{P} 0$ & & 4 & & & & & & & & & 3, & 4 \\
1 & 00 & &. & & & & & & & & & 9 & \\
& 1 & 4 & 5 & 4 & 4 & 4 & 3 & 5 & 3 & 4 & 4 & 5 & \\
\hline
\end{tabular}

\section{b. Aspek Keahlian}

Untuk penghitungan core factor dan secondary factor untuk aspek keahlian, cara pengerjaan sama dengan aspek kapasitas kecerdasan. Terlebih dahulu menentukan sub-aspek mana yang menjadi core factor dari aspek kapasitas kecerdasan (misalnya sub aspek 1 dan 2) maka sub-aspek sisanya akan menjadi secondary factor. Kemudian nilai core factor dan secondary factor ini dijumlahkan sesuai rumus dan hasilnya dapat dilihat pada Tabel 12, berikut cara pengerjaannya:

$$
\begin{gathered}
N C F=\frac{4,5+4.5}{2}+\frac{9}{2}+4,5 \\
N C F=\frac{4}{1}=4
\end{gathered}
$$

TABEL 12

TABEL PENGELOMPOKKAN BOBOT NILAI GAP ASPEK KEAHLIAN

\begin{tabular}{|l|l|l|l|l|l|l|}
\hline No & ID & BDB & MPM & MBI & CF & SF \\
\hline 1 & P0001 & 4.5 & 5 & 4 & 4,5 & 4 \\
\hline
\end{tabular}

\section{c. Aspek Perilaku}

Untuk penghitungan core factor dan secondary factor untuk aspek perilaku, sama seperti perhitungan pada aspek kapasitas kecerdasan dan keahlian. Terlebih dahulu menentukan sub-aspek mana yang menjadi core factor dari aspek kapasitas kecerdasan (misalnya sub-aspek 1 dan 2) maka sub-aspek sisanya akan menjadi secondary factor. Kemudian nilai core factor dan secondary factor ini dijumlahkan sesuai rumus dan hasilnya dapat dilihat pada Tabel 13, berikut cara pengerjaannya:

$$
\begin{gathered}
N C F=\frac{4,5+4.5}{2}=\frac{9}{2}=4,5 \\
N C F=\frac{5+4}{2}=\frac{9}{1}=4
\end{gathered}
$$

TABEL 13

TABEL PENGELOMPOKKAN BOBOT NILAI GAP ASPEK PERILAKU

\begin{tabular}{|l|l|l|l|l|l|l|l|}
\hline No & ID & DO & IN & ST & CO & CF & SF \\
\hline 1 & P0001 & 4.5 & 4.5 & 5 & 4 & 4,5 & 4 \\
\hline
\end{tabular}

\section{Penghitungan Nilai Total}

Dari hasil perhitungan dari tiap aspek di atas kemudian dihitung nilai total berdasar prosentase dari core dan secondary yang diperkirakan berpengaruh terhadap kinerja tiap-tiap profil. Contoh perhitungan dapat dilihat pada rumus di bawah ini:

$(x) \% N C F(k a, k e, p e)+(x) \% N S F(k a, k e, p e)=N(k a$, ke, pe)

Keterangan:

(ka,ke,pe) : (Kecerdasan, Keahlian, Perilaku)

$N C F(k a$ ke,pe) : Nilai Rata-rata Core Factor

$N S F(k a$ ke pe) : Nilai Rata-rata Secondary Factor $N(k a, k e, p e)$ : Nilai Total Dari Aspek $(x) \% \quad$ : Nilai Persen Yang Diinputkan

Untuk lebih jelasnya perhitungan nilai total dapat dilihat pada contoh perhitungan aspek kapasitas 
kecerdasan, aspek keahlian dan aspek perilaku dengan nilai persen $60 \%$ dan $40 \%$, berikut ini:

1. Aspek Kapasitas Kecerdasan

$N k a=(60 \% \times 3,9)+(40 \% \times 4)=3,94$

TABEL 14

TABEL NILAI TOTAL ASPEK KAPASITAS KECERDASAN

Page $\mid 50$

\begin{tabular}{|l|l|l|l|l|}
\hline No & ID & $\begin{array}{l}\text { Core } \\
\text { Factor }\end{array}$ & $\begin{array}{l}\text { Secondary } \\
\text { Factor }\end{array}$ & Nka \\
\hline 1 & P0001 & 3,9 & 4 & 3,94 \\
\hline
\end{tabular}

2. Aspek Keahlian

Nke $=(60 \% \times 4,5)+(40 \% \times 5)=4,7$

TABEL 15

TABEL NILAI TOTAL ASPEK KEAHLIAN

\begin{tabular}{|l|l|l|l|l|}
\hline No & ID_Peng & $\begin{array}{l}\text { Core } \\
\text { Factor }\end{array}$ & $\begin{array}{l}\text { Secondary } \\
\text { Factor }\end{array}$ & Nke \\
\hline 1 & P0001 & 4,5 & 5 & 4,7 \\
\hline
\end{tabular}

3. Aspek Perilaku

Npe $=(60 \% \times 5)+(40 \% \times 4)=4,3$

TABEL 16

TABEL NILAI TOTAL ASPEK PERILAKU

\begin{tabular}{|l|l|l|l|l|}
\hline No & ID_Peng & $\begin{array}{l}\text { Core } \\
\text { Factor }\end{array}$ & $\begin{array}{l}\text { Secondary } \\
\text { Factor }\end{array}$ & Npe \\
\hline 1 & P0001 & 4,5 & 4 & 4,3 \\
\hline
\end{tabular}

E. Perhitungan Penentuan Ranking

Hasil akhir dari proses Profile Matching adalah ranking dari kandidat yang diajukan untuk mengisi suatu lowongan. Penentuan ranking mengacu pada hasil perhitungan tertentu. Perhitungan tersebut dapat ditunjukkan pada rumus di bawah ini:

Ranking $=(x) \% N k a+(x) \% N k e+(x) \% N p e$

Keterangan:

$\begin{array}{ll}\text { Nka } & \text { : Nilai Kapasitas Kecerdasan } \\ \text { Nke } & \text { : Nilai Sikap Kerja } \\ \text { Npe } & \text { : Nilai Perilaku } \\ (x) \% & \text { : Nilai Persen Yang Diinputkan }\end{array}$

Sebagai contoh dari rumus untuk perhitungan ranking di atas maka hasil akhir dari calon pegawai dengan Id_kary P0001 dengan nilai persen $=20 \%$, $30 \%$ dan 50\%. Dapat dilihat pada Tabel 17 di bawah ini:

Ranking $=(20 \% 3,94)(30 \% 4,3)(50 \% 4,7)$

Ranking $=0,78+1,29+2,35$

Ranking $=4.428$
TABEL 17

TABEL HASIL AKHIR PROSES PROFILE MATCHING

\begin{tabular}{|l|l|l|l|l|l|}
\hline No & ID_Peng & Nka & Nke & Npe & Hasil Akhir \\
\hline 1 & P0001 & 0,78 & 1,29 & 2,35 & 4.428 \\
\hline
\end{tabular}

Setelah tiap kandidat mendapatkan hasil akhir seperti contoh pada Tabel 17 di atas, maka dapat ditentukan peringkat atau ranking dari tiap kandidat berdasarkan

pada semakin besar nilai hasil akhir maka semakin besar pula kesempatan untuk lulus menjadi pegawai yang ada, dan begitu pula sebaliknya.

\section{KESIMPULAN DAN SARAN}

Kesimpulan dari hasil perancangan dan implementasi sistem pendukung keputusan penilaian pegawai dapat disimpulkan sebagai berikut :

1. Sistem dapat melakukan pendataan data alternative penilaian pegawai serta data kriteria dan sub kriteria.

2. Sistem dapat melakukan pengambilan keputusan dengan menghitung nilai core factor dan secondary factor pada masing-masing alternative dan sub kriteria sehingga dapat diberikan keputusan pegawai yang berprestasi kinerjanya.

\section{REFERENSI}

[1] Kristiana, Titin. 2015. Penerapan Profile Matching Untuk Penilaian Kinerja Pegawai Negeri Sipil (PNS). ISSN: 19781946. Jakarta: Jurnal Pilar Nusa Mandiri Vol. XI, No. 2 September 2015: 161-170.

[3] Muharto dan Arisandy Ambarita. 2016. Metode Penelitian Sistem Informasi: Mengatasi Kesulitan Mahasiswa dalam Menyusun Proposal Penelitian. Sleman: Deepublish Publisher.

[4] Nofriansyah, Dicky. 2014. Konsep Data Mining VS Sistem Pendukung Keputusan. Yogyakarta: Deepublish.

[5] Setiawan, Adil \& Surya Darma. 2015. Implementasi Decision Support System Dalam Penseleksian Calon Anggota Baru Badan Eksekutif Mahasiswa (BEM) dengan Metode GAP Kompetensi (Studi Kasus: Universitas Potensi Utama). ISSN: 2302-3805. Medan: Seminar Nasional Teknologi Informasi dan Multimedia 6-8 Februari 2015: 127-132.

[6] Sianturi, Fricles Ariwisanto. 2015. Implementasi Sistem Pendukung Keputusan Kenaikan Jabatan Guru Dengan Model Profile Matching Pada Sekolah SMA Swasta Raksana Medan. ISSN: 2088-3943. Medan: Jurnal Mantik Penusa Vol. 18, No.2 Desember 2015: 44-52.

[7] Zulfikar dan I. Nyoman Budiantara. 2014. Manajemen Riset dengan Pendekatan Komputasi Statistika. Yogyakarta: Deepublish. 